Synthesis, part of a Special Feature on The Governance of Adaptation

\title{
Can Adaptive Comanagement Help to Address the Challenges of Climate Change Adaptation?
}

\author{
Ryan Plummer ${ }^{1,2}$
}

\begin{abstract}
A shift is taking place within environmental governance that draws attention to modes and instruments that respond to system dynamics, uncertainty, and contested values. Adaptive comanagement is one process being advanced to make governance operational as it emphasizes collaboration among diverse actors, functions across scales and levels, and fosters learning though iterative feedback. Although extensive experience with adaptive comanagement has been gained in relation to other environmental and resource issues, its potential contribution to the governance of adaption is largely unexplored. This paper probes how adaptive comanagement might offer support to climate change adaptation and identifies gaps in knowledge requiring attention. In drawing upon existing literature and applied experiences, it is argued that adaptive comanagement may contribute to climate change adaptation by building generalized adaptive capacity as well as providing a novel institutional arrangement to generate adaptive responses. At the same time, several questions emerge about adaptive comanagement in this context. Considerations are thus discussed for adaptive comanagement scholarship and application in addressing the challenge of climate change adaptation.
\end{abstract}

Key Words: adaptive capacity; adaptive comanagement; adaptive responses; climate change adaptation; environmental governance

\section{INTRODUCTION}

Human activities drive global environmental change in the era of the Anthropocene and are pushing the Earth system outside the stable state of the Holocene (Rockström et al. 2009). Climate change is one planetary boundary already transgressed and analysis by Rockström et al. (2009) reveals that continued change at the present rate will cause significant erosion of resilience for Earth system functioning. Although variables such as temperature, precipitation and, evapotranspiration fluctuated within a relatively narrow range in the Holocene, anthropogenic climate change is altering the variability and predictability of natural systems, and thus undermining the concept of stationarity (Milly et al. 2008). As a result, past approaches and technical designs are of limited utility for future conditions (NRC 2009, de Loë and Plummer 2010). Emerging research on complex systems highlights further challenges to views of stability and predictability. For example, Scheffer et al. (2009) draw attention to critical thresholds or tipping points that prompt abrupt change as a system shifts from one state to another. Although mitigation is essential in this context to slow the rate of climate warming, the Intergovernmental Panel on Climate Change (IPCC 2007) observes that even the most aggressive efforts will not prevent climate change, and thus, that adaptation is essential.

In this context, "dealing with climate adaptation not only demands a rethink of how we arrange our social-ecological or social-technical systems but also how we govern them" (van Nieuwaal et al. 2009:8). As the introductory text to this Special Feature makes clear, the concept of governance is highly relevant for adaptation because societal actors at a variety of levels are building adaptive capacity, undertaking adaptive actions, and developing adaptation policies. Simultaneously, pressing issues are emerging regarding the extent to which governors need to deliberately intervene, at what levels, and the adequacy of responses emerging by actors in communities. This raises important questions about the appropriateness and effectiveness of governance modes and instruments in addressing the challenge of adaptation.

In taking up these important questions, this paper investigates how adaptive comanagement may help to address climate change adaptation. The transition underway in environmental governance, its hybridization of forms and emerging key challenges serve as an entrée into adaptive comanagement. Because adaptive comanagement has not typically been employed to address climate change adaptation, this conceptual investigation draws upon existing literature and preliminary applied experiences to (1) explore how it might offer support and (2) identify gaps in knowledge requiring attention to advance this governance strategy.

\section{THE CHANGING LANDSCAPE OF ENVIRONMENTAL GOVERNANCE}

Governance is goal oriented and steers society toward a particular end through deliberate interventions (Kooiman 1993). All forms of governance are concerned about what could and what should be; they commonly address (1) categories of actors and their roles, (2) an intention for change in relationship between actors and their roles, and (3) the social context in which change is required (Glasbergen 1998). Biermann et al. (2009:3) define Earth system governance as 
"the interrelated and increasingly integrated system of formal and informal rules, rule-making systems, and actor-networks at all levels of human society (from local to global) that are set up to steer societies towards preventing, mitigating, and adapting to global and local environmental change and, in particular, earth system transformation, with the normative context of sustainable development."

Many models of governance exist relating to environmental policy (Glasbergen 1998); each reflects norms about societal organization and taking a position on how and who should address environmental challenges. Glasbergen (1998) offers a typology encompassing the five types: regulatory control, market regulation, civil society, contextual control and selfregulation, and co-operative management. Although regulatory control provides the basis of environmental policy (Glasbergen 1998) and has made considerable headway with some environmental problems of the 20th century, its limitations are now realized because it alone fails to reconcile conflicts and polarized positions of actors, is unable to enforce compliance, and is limited in effectiveness under conditions of uncertainty and change that characterize contemporary environmental challenges (Holling and Meffe 1996, Kettl 2002). Alternatively, it is argued that the retreat from a regulatory approach or a 'rolling back of the state' is due to neoliberal reforms (Himley 2008, Lockwood and Davidson 2010). Attention has thus been shifting away from 'government' and toward alternative models of governance (Himley 2008, Pahl-Wostl et al. 2008, de Loë et al. 2009).

Although concentrating on the types of governance is useful for the purpose of highlighting their defining attributes, Glasbergen (1998) notes that in practice they frequently combine and are not mutually exclusive. Lemos and Agrawal (2006) illustrated this concept by bridging ideal types of environmental governance models (state, market, community) in relation to hybridized or boundary crossing forms, e.g., comanagement, public-private partnerships, private-social partnerships. Novel conceptualizations of environmental governance are emerging in light of complexity and uncertainty, often associated with climate or environmental change. Bulkeley (2005), for example, argues that new spatial grammars (i.e., dimensions of space concerning identities, institutions, and processes are articulated in reference to a phenomenon) are required to comprehend hybrid forms and their social and ecological implications. Others, such as Paavola (2007), concentrate on the role(s) of institutions and institutional design solutions in this reconceptualization. Duit and Galaz (2008) tackle the issues of complexity and uncertainty head-on and offer a complex adaptive system perspective on governance.

A transition is thus underway in environmental governance. This shift involves environmental governance being reconceptualized from an overly structural or static view and toward a dynamic perspective that stresses the ability to navigate interconnected and multilevel social-ecological systems (Lemos and Agrawal 2006, Folke 2007, Ostrom 2007, Galaz et al. 2008, de Loë et al. 2009, Plummer and Armitage 2010). Several recent efforts (Lemos and Agrawal 2006, Biermann et al. 2009, de Loë et al. 2009, Lockwood et al. 2010, Reed and Bruyneel 2010) draw attention to changes in what governance implies, how it occurs, and what it seeks to achieve. In bringing together the concerns identified with the shift in environmental governance, Armitage et al. (2012:247-248) draw attention to “... five key concepts or issues in environmental governance: (1) recognition of the importance of fit and scale; (2) fostering adaptiveness, flexibility, and learning; (3) coproducing knowledge from diverse sources; (4) understanding the emergence of new actors and their roles in governance; and (5) changing expectations about accountability and legitimacy."

Set against this background, several strategies, e.g., adaptive governance, cogovernance, adaptive comanagement, are emerging to make such governance operational. These strategies similarly assert requirements of “... collaboration among heterogeneous actors with diverse interests, institutions that are flexible and nested across scales and levels, and analytic deliberation that develops understanding through multiple knowledge systems; builds trust through repeated interactions; and fosters learning and adaptive and continuous feedback through continuous feedback" (Plummer and Armitage 2010:5, see also Dietz et al. 2003, Folke et al. 2005).

Adaptive comanagement specifically is described as a strategy for governance of social-ecological systems (Armitage et al. 2009, Kofinas 2009, Plummer 2009, Cundill 2010, Cundill and Fabricius 2010). Huitema et al. (2009) identify the connection between governance and adaptive comanagement and opportunity for gaining insights into this institutional prescription and its performance by collating studies. In taking up their suggestion, Plummer et al. (2013) conducted a systematic review and analysis of the adaptive comanagement literature to better understand its relationship with environmental governance. Their findings illuminate a blurred or fuzzy boundary between the two concepts, the contributions of adaptive comanagement scholarship to each of the emerging concerns of environmental governance (as identified above in the work of Armitage et al. 2012), and the advantaged position of adaptive comanagement in reference to navigating dynamic and multilevel systems. Although in this paper, I concentrate on adaptive comanagement, it is important to acknowledge that the requirements to meet the shift in governance may take several forms, and correspondingly, are open to a range of benefits and/or challenges.

\section{ADAPTIVE COMANAGEMENT}

Adaptive comanagement draws upon the collaborative and adaptive narratives that have been gaining traction in resource and environmental management over the past 25 years. The 
precise introduction of the term adaptive comanagement, and the synonym adaptive collaborative management, dates to the mid-1990s (Plummer and Armitage 2007). Adaptive comanagement is broadly understood as "a process by which institutional arrangements and ecological knowledge are tested and revised in a dynamic, on-going, self-organized process of learning-by-doing" (Folke et al. 2002:20). As a bridge spanning its adaptive and collaborative foundations, adaptive comanagement engenders a distinct approach. Berkes et al. (2007) argue that adaptive comanagement uniquely forges linkages (vertical and horizontal) for shared learning-by-doing, has a medium to long temporal horizon with multiple iterative cycles of learning and adaptation, is multiscale in scope and all-encompassing in terms of the needs and relationships of actors, and focuses on building capacity for all involved. In so doing, adaptive comanagement “... creates an 'adaptive dance' between resilience and change with the potential to sustain complex social-ecological systems" (Olsson et al. 2004a:87). This potential has resulted in a burgeoning area of scholarship and application (see Plummer et al. 2012 for a summary of this literature).

What adaptive comanagement entails and can accomplish is perhaps best illustrated by experiences in the Kristianstads Vattenrike area of Sweden. A rich series of investigations have documented the events and processes associated with this wetland landscape and its governance over the past 35 years (see Olsson et al. 2004b, Schultz 2009, Hahn 2011, upon which this summary is based). The name Kristianstads Vattenrike, roughly translated, means both "the water realm" and "riches." In an effort to protect ecosystem services and values of the Lower Helgeå River, the area was designated as a Ramsar Conservation Site and identified as important to Sweden for conservation by the mid-1970s. Despite conservation plans and efforts throughout the 1980s, local stewards and the government documented the continued erosion of natural and cultural values such as eutrophication of lakes, declines in using the flooded meadows, and reductions in the populations of birds. The efforts of a key individual (identified as SEM) in bringing about adaptive comanagement are highlighted as being particularly significant in this case. SEM was aware of actors at different levels engaged in similar activities and was able to cultivate a network of individuals and organizations concerned about ecosystem changes through trust and dialogue. He was also able to articulate a clear vision and rationale for connecting these actors around a common cause and to garner support from key individuals in the municipal executive board. In 1989 the Ecomuseum Kristianstads Vattenrike (EKV) was formed to assist the municipality in managing the ecosystem. This flexible and dynamic organization facilitated collaborative processes with actors at a range of scales, local through international, to restore and keep the values of the area. While reporting to the municipal board, it did not have any regulatory authority. The activities of the EKV included conducting inventories, undertaking mapping, increasing accessibility to the wetlands, providing information, and monitoring. These activities are usually project-based and thus provide opportunities for selforganization, learning, and adjustments. They typically involve diverse actors and draw upon different types of knowledge, thus enhancing capacity for adaptation. Over time the activities and scope of the EKV expanded beyond the initial area. In 2005 the area was designated a UNESCO Biosphere Reserve and the EKV changed its name to Biosphere Office. In 2010 Naturum opened as a center for interpretive displays, conferences, schools, and restaurants. The multilevel network was decisive for protecting the project, again signaling enhanced resilience adaptability (see Hahn 2011).

Adaptive comanagement is garnering considerable attention because it is anticipated to enhance the robustness of socialecological systems (Olsson et al. 2004a) and orient them toward sustainable trajectories (Folke et al. 2002). It is also identified to potentially address the problem of fit where social and ecological dynamics do not match (Olsson et al. 2007) and build adaptive capacity (Armitage 2007, Fabricius et al. 2007). This enthusiasm for the outcomes of adaptive comanagement has been tempered by valuable critique. For example, Nadasdy (2007) highlights the need to critically question the sociopolitical context and framing of interests, and Fennell et al. (2008) observe how adaptive comanagement is not immune from tensions of efficiencies, equity, and marginalization.

\section{ADAPTIVE COMANAGEMENT AND CLIMATE CHANGE ADAPTATION}

The introduction to the Special Feature poses questions about the appropriateness and effectiveness of governance modes and instruments in addressing the challenges of climate change adaptation. Scholars of adaptive comanagement are clear that it is not a governance panacea and needs to be tailored to particular contexts (Armitage et al. 2009, Berkes 2009, Plummer and Hashimoto 2011). In this paper, I explore how adaptive comanagement may support climate change adaptation and identify gaps in knowledge requiring attention to advance it in this context.

\section{How might adaptive comanagement support climate change adaptation?}

Conceptualizations of adaptive capacity and adaptation serve as an entrée to investigate how adaptive comanagement might support climate change adaptation. Adaptive capacity, in the context of climate change, concerns the ability of a system to modulate exposure and sensitivity and influence its vulnerability (e.g., Adger 2003, Smit and Wandel 2006, Engle 2011). In the social-ecological systems literature the notion of adaptive capacity is often positioned in relation to the concept of resilience. Adaptive capacity from this perspective concerns “... the ability of a social-ecological system to cope with novel 
situations without losing options for the future" (Folke et al. 2002:17). In building upon the diverse array of meanings associated with adaptive capacity, Plummer and Armitage (2010:6) take an integrative perspective and frame the concept within scholarship on institutional dynamics and environmental governance. In so doing, they argue that “... adaptive capacity is determined by the suite of resources (technical, financial, social, institutional, political) held, and the social processes and structures through which they are employed and mediated (i.e., governance)."

Adaptive capacity has a close relationship with the concept of adaptation. Adaptive capacity manifests in adaptations (Smit and Wandell 2006) and in simple terms describes the ability of a system to adapt (Engle 2011). Adaptation, in the context of environmental change, is "an adjustment in ecological, social, or economic systems in response to observed or expected changes in environmental stimuli and their effects and impacts in order to alleviate adverse impacts of change" (Nelson et al. 2007:398). The concerns and intricacies of the adaptation research agenda are considerably broad and reviewing them is beyond the scope of this paper (see Smithers and Smit 1997, Smit and Pilifosova 2003, Smit and Wandel 2006, Engle 2011). However, it is important to recognize that adaptive comanagement is not equally suited to the entire realm of adaptation. Smit and Pilifosova (2001) characterize and differentiate types of adaptation according to the nature of the system (natural vs. human), who adapts (private vs. public), and its timing/intention (anticipatory vs. reactive). More recently, Tompkins and Eakin (2012) examine the suppliers and beneficiaries of adaptation. They set out a typology of institutional arrangements and challenges consisting of four domains: public provision of adaptation goods for public benefit; public provision of adaptation for private benefit; private adaptation for private benefit; and private provision of adaptation goods for public benefit. In following this categorization of the adaptation realm, one would have limited expectations of adaptive comanagement to assist with the first three domains. For example, adaptive comanagement would be of little help in supporting market mechanisms such as insurance. It is the domain of private adaptation for public benefit in which adaptive comanagement is best positioned to offer support as it brings together public and private actors to address an environmental or resource problem, typically a common resource, with diffuse benefits not accruing to the individuals.

Although there is relatively little experience with adaptive comanagement in relation to climate change, there are two main ways in which it may support adaptation in this context. First, adaptive comanagement builds generalized adaptive capacity (e.g., Armitage 2007, Fabricius et al. 2007, Armitage et al. 2009, Plummer et al. 2012). General adaptive capacity refers to characteristics that promote the ability to respond to almost any kind of challenge, e.g., available wealth or skilled human resources, whereas specific adaptive capacity concerns sector specific skills, knowledge, and systems (Bergkamp et al. 2003). These factors generally fall under the literature on determinants of adaptive capacity and across scales it has been found to be influenced by economic development, technology, and social factors (Nelson et al. 2007). Armitage (2005) draws attention to the operational (e.g., technical, financial, social, institutional, political) and strategic (e.g., power, scale, knowledge, community, culture) factors that influence adaptive capacity in community-based natural resource management. In adaptive comanagement specifically, there are several factors identified that foster adaptive capacity. For example, Fabricius et al. (2007) observe that adaptive comanagers have adaptive capacity, which “... becomes possible through leadership and vision, the formation of knowledge networks, the existence or development of polycentric institutions, the establishment and maintenance of links between culture and management, the existence of enabling policies, and high levels of motivation in all role players." Armitage et al. (2009) describe how adaptive comanagement additionally encourages the key ingredients of adaptive capacity by encouraging flexibility and innovation.

Perhaps most pointedly, Pelling et al. (2008:870) observe that "seeing adaptation in terms of learning highlights both material adaptation and institutional modification as valid adaptive strategies. If learning itself is considered a kind of adaptive behavior, then this opens up questions surrounding the process through which actors can learn to learn (or learn to be adaptive)." A central line of inquiry for those studying adaptive comanagement is about learning, and in particular the functioning of social or multiple loop learning (Plummer and FitzGibbon 2007, Armitage et al. 2008, Berkes 2009, Plummer 2009). Specific attention to learning and knowledge within comanagement in relation to adapting to climate change comes from work in the Arctic (Berkes and Armitage 2010, Armitage et al. 2011). This work examines linkages among knowledge, learning, and adaptation in relation to comanagement cases of Narwhal (Monodon monoceros), Beluga (Delphinapterus leucas), and Dolly Varden Char (Salvelinus malma). Insights gained through the analysis draw attention to how knowledge coproduction may trigger or act as a mechanism for learning, which emerged in the cases as a key type of adaptation.

Second, adaptive comanagement may act as a novel institutional arrangement through which adaptive responses to climate change may be generated. As Adger (2003:33) points out, "adaptive capacity is only potential until there are governance institutions that make it realizable." In the Canadian Arctic for example, comanagement institutions such as the Fisheries Joint Management Committee and the Nunavut Wildlife Management Board are new institutional processes through which responses to the impacts of climate change are being generated (Berkes and Armitage 2010). 
Although such comanagement arrangements were not initially envisioned to address climate change per se, "these arrangements provide emerging networks, or horizontal and vertical linkages that give rise to new social practices and stakeholder interactions, and thus a greater ability to cope with variability and build longer-term adaptive responses to minimize risk and uncertainty" (Armitage et al. 2011:995).

By extension, the idea of introducing adaptive comanagement as a pathway for climate change adaptation is emerging. In one of the few applied examples connecting adaptive comanagement and climate change, Locatelli et al. (2008) argue that adaptive comanagement is a good example for forestry because it builds upon three prongs crucial for climate change adaptation: understanding diverse views of many stakeholders; developing better mechanisms for learning from experiences; and addressing power inequities. Another example comes from the Niagara Region of Canada in which a social-ecological inventory (SEI) was used to prime the governance system and lead into an adaptive comanagement process (see Baird et al., in press). Adaptive comanagement in this example was approached as an action research project to examine the process and outcomes in relation to the context of climate change adaptation. The researchers initiated and facilitated the iterative and participatory processes, which involved 32 stakeholders from various sectors. Over a 14 month period the stakeholders routinely interacted and formed a steering committee. In addition to attending workshops and discussing the impacts of climate change on the Niagara Region, the group developed a climate charter, was instrumental in commissioning a climate change report for the Region, and expressed intention to collaborate on a climate change action plan. The longitudinal design of the research was truncated because of funding cuts and the researchers were notified that the steering committee disbanded a few months after the end of the study. Analysis of the case is presently underway in regard to learning that occurred (J. Baird, R. Plummer, D. Huitema, and C. Haug, unpublished manuscript) and the initiation of adaptive comanagement through such intervention using social network analysis (J. Baird, R. Plummer, and O. Bodin, unpublished manuscript).

\section{Emerging questions for adaptive comanagement in relation to climate change adaptation}

In the process of exploring how adaptive comanagement might support climate change adaptation several knowledge gaps emerged. These gaps are framed as a series of questions and the discussion accompanying each question draws attention to considerations for adaptive comanagement scholarship and application in moving forward with climate change adaptation.

Can further insights be gained about how adaptive comanagement as a governance strategy builds general adaptive capacity and generates adaptive responses? Developing a fuller understanding of adaptive comanagement is a critical challenge. The findings from a recent systematic review and analysis of adaptive comanagement literature reveal that existing research is insufficient in terms of definitional clarity, measurement, and findings to answer: the extent to which variables, e.g., social and political context, properties of networks, assets employed by agencies, organizations and individuals, attributes of organizations and individuals, key functions of individuals, can be traded off; which variables always need to be present; and the variables that can improve its quality (Plummer et al. 2012). Addressing these present challenges would make possible the collection of robust and comparable evidence about how adaptive comanagement builds general adaptive capacity and generates adaptive responses. Gaining insights specific to variables associated with adaptive comanagement, e.g., learning, knowledge, networks, leadership, is also required to understand the roles they play within the dynamic process and to comprehend their influence on outcomes. These are formidable challenges for adaptive comanagement scholarship at present. Pursuing a fuller understanding of adaptive comanagement in a systematic and rigorous manner raises the prospects of developing theory to help guide humanenvironment interactions (Plummer et al. 2012).

\section{How does the context of climate change influence adaptive comanagement?}

Because knowledge and experience of adaptive comanagement in the specific context of climate change adaptation is limited, an underlying assumption of this paper is that scholarship on adaptive comanagement in other environmental contexts is transferable to some degree. Determining the degree to which such knowledge and experience is indeed transferable as well as understanding how this context shapes the adaptive comanagement process is essential. For example, Armitage et al. (2009:100) derive "ten conditions for successful adaptive co-management" from a variety of empirical cases that must be present to some extent for a successful outcome. Conditions of success they identify that present immediate challenges in regard to climate change include: well-defined resource system, small-scale resource use contexts, reasonably clear property rights, and national and regional policy environment. The context of climate change seems to add a level of 'abstraction' and a lack of immediacy, which may precipitate stakeholders to act in other adaptive comanagement situations. Being aware of how adaptive comanagement manifests in different situations is also critical. Plummer and Hashimoto (2011) offer a framework for researchers and policy makers in this regard. They argue that adaptive comanagement can thus be tailored to a context, and in turn, the adaptability and fit enhanced.

How does adaptive comanagement compare to, and connect with, other governance strategies for climate change adaptation?

Both parts of this double-barreled question require consideration and warrant future investigation. The first part 
of the question identifies the need to clearly identify the outcomes from adaptive comanagement and evaluate its successes or failures. Although evaluation of adaptive comanagement is critical, few studies have undertaken such an assessment (Plummer and Armitage 2007, Cundill and Fabricius 2010). Efforts to assess the effectiveness of institutional prescriptions of adaptive comanagement based on evidence from the existing literature were inconclusive and led to the call for more empirical and theoretical work (Huitema et al. 2009). The subsequent systematic review of adaptive comanagement literature to 2010 found little basis for meaningful comparisons and thus identified evaluating outcomes and establishing generalizable patterns of how components of adaptive comanagement relate to goals and outcomes as a critical future challenge (Plummer et al. 2012).

The second part of this question draws attention to the need for multiple governance strategies for climate change adaptation and consideration of their interplay. Climate change is an example of a wicked problem with global to local interdependencies. The very definition of Earth system governance offered by Biermann et al. (2009) earlier highlights the interrelations and increasing integration of institutions as well as connections between mitigation and adaptation to environmental change. Duit and Galaz (2008:318) observe that "... different governance systems might coexist and interact over societal levels" and that "... the combination of different governance systems will be decisive for the impact of disturbances and surprises." Adaptive comanagement is one example of an emerging governance strategy and determining how it works with others will be critical. Adaptive comanagement works across levels and scales, but usually focuses on an identifiable landscape or small scale. Attention is required as to how changes prompted by adaptive comanagement may cascade upward. Recent work by Galaz et al. (2012) is a reminder that all governance strategies present both opportunities and limitations. Future research is required to better understand what those are for adaptive comanagement generally, and specifically in regard to climate change.

What if adaptation is not appropriate and a different system trajectory is required?

Adaptive strategies and capacity for adaptation are essential to dealing with change. However, it is possible that adaptability can 'mask business as usual' and that they may be maladaptive, undermine long term solutions, and cause undesirable consequences (Folke et al. 2003, Scheffer 2009). An important distinction is required between adaptability, capacity for reconfiguration within a social-ecological regime, and transformability, the capacity to create a fundamentally new social-ecological system and shift to a social-ecological trajectory (Walker et al. 2004, Lebel et al. 2006). Responses, even adaptive ones, that fail to respond adequately to system feedbacks can create lock-in or rigidity traps that cause persistence along established paths as well as reduced capacity to innovatively respond to opportunities (see Folke et al. 2010, Olsson et al. 2010). Understanding when and how these situations occur and building capacity to transform conditions at particular scales are essential, and complimentary, processes (Walker et al. 2004, Lebel et al. 2006, Olsson et al. 2010). Despite recognizing the need for transitions and transformations, few examples based on empirical cases exist and "there is still a lack of understanding on how to transform SES into new, improved trajectories that sustain and enhance ecosystem services and human well-being" (Olsson et al. 2010:264). Adaptive comanagement appears to be an exception to this observation. Building upon work in Kristianstads Vattenrike as well as navigating transitions in other cases (e.g., Olsson et al. 2006, 2008), Olsson et al. (2010) introduce the idea of transformative capacity. From their experiences, building capacity for transformation requires understanding where you are, determining where to go, and devising ways to get there. They conclude that "important questions for future research on SES transformations are what needs to be transformed and how transformations happen" (2010:281). Adaptive comanagement thus might be particularly applicable to deliberative transformational change.

\section{CONCLUSIONS}

The title of this paper provocatively posed an ambitious question to adaptive comanagement scholarship: can it help to address the challenge of climate change adaptation? There are many domains of adaptation to which contributions from adaptive comanagement are unlikely. It is the domain of private adaptation for public benefit where contributions from adaptive comanagement may be anticipated as it brings together actors in a problem solving process with diffuse benefits not accruing to the individuals. In drawing upon present knowledge of and experiences with adaptive comanagement, it was argued that it may support climate change adaptation by building generalized adaptive capacity and offering a novel institutional arrangement to generate adaptive responses to climate change.

Tompkins and Eakin (2012:6) observe that "the case of private production of adaptation public goods is a special case that is not completely congruent with examples of coproduction and co-management." The conceptual exploration thus identified and discussed questions that emerged in relation to the proposition that adaptive comanagement may support climate change adaptation. Despite the growing abundance of adaptive comanagement literature, the extent to which robust conclusions can be systematically drawn from evidence is presently limited because of inconsistent definitions and varied measurements (Plummer et al. 2012). A research agenda that overcomes these challenges will increase understanding how adaptive comanagement builds general adaptive capacity and generates adaptive responses. As 
experience is gained with adaptive comanagement for climate change adaptation, insights may be gained about tailoring the process to this context. Adaptive comanagement is one governance strategy among many for climate change adaptation. An important avenue for future research is to examine its salience as well as relationship to other governance strategies. Finally, adaptive comanagement may serve as a useful governance strategy to consider if adaption is appropriate or if transformations are necessary.

Undertaking adaptive comanagement to address climate change adaptation will not be an easy task because it is neither a set prescription nor a governance panacea. At the same time, it offers a viable way to foster governance and build capacity to navigate change. As Olsson et al. (2010:281) argue:

...if we can increase our understanding of SES transformations and provide strategies and guidelines for initiating and navigating SES' transformations, we could better prepare for and potentially speed up the responses to the rapid changes in the capacity of the earth's ecosystems to sustain our development and civilization. The issue is pressing, considering the windows of opportunity for transformations towards sustainability that are currently wide open due [to] rapid, pervasive global changes in many dimensions.

Responses to this article can be read online at: http://www.ecologyandsociety.org/issues/responses. php/5699

\section{Acknowledgments:}

This paper builds upon past opportunities afforded to think and write about adaptive comanagement in relation to climate change at the Northern Political Economy Symposium 2011: Climate Change in the Barents Region CLIM-BEAR and through work for the Adaptation and Impacts Research Section of Environment Canada. The organizers of the Symposium are warmly thanked for their kind invitation and support. It is also informed by collaborative research with Dave Huitema and Constanze Haug on learning in relation to community climate change adaptation. I greatly appreciate feedback received on this manuscript from Derek Armitage, Julia Baird, Kerrie Pickering, and Lisen Schultz. Samantha Purdy is gratefully acknowledged for her assistance with the manuscript. Participants in the Niagara Climate Change Network are thanked for their efforts. Empirical work informing this paper was supported through a Grants and Contributions Agreement between Brock University and Environment Canada.

\section{LITERATURE CITED}

Adger, W. N. 2003. Social aspects of adaptive capacity. Pages 29-49 in J. B. Smith, R. J. T. Klein, and S. Huq, editors. Climate change, adaptive capacity and development. Imperial College Press, London, UK.

Armitage, D. 2005. Adaptive capacity and community-based natural resources management. Environmental Management 35(6):703-715. http://dx.doi.org/10.1007/s00267-004-0076-Z

Armitage, D. 2007. Building resilient livelihoods through adaptive co-management: the role of adaptive capacity. Pages 62-82 in D. Armitage, F. Berkes, and N. Doubleday, editors. Adaptive comanagement: collaboration, learning and multilevel governance. University of British Columbia Press, Vancouver, British Columbia, Canada.

Armitage, D., F. Berkes, A. Dale, E. Kocho-Schellenberg, and E. Patton. 2011. Co-management and the co-production of knowledge: learning to adapt in Canada's Arctic. Global Environmental Change 21(3):995-1004. http://dx.doi. org/10.1016/j.gloenvcha.2011.04.006

Armitage, D., R. de Loë, and R. Plummer. 2012 Environmental governance and its implications for conservation practice. Conservation Letters 5(4):245-255. http://dx.doi.org/10.1111/ j.1755-263X.2012.00238.X

Armitage, D., M. Marschke, and R. Plummer. 2008. Adaptive co-management and the paradox of learning. Global Environmental Change 18:86-98. http://dx.doi.org/10.1016/j. gloenvcha.2007.07.002

Armitage, D. R., R. Plummer, F. Berkes, R. I. Arthur, I. J. Davidson-Hunt, A. Diduck, N. C. Doubleday, D. S. Johnson, M. Marschke, P. McConney, E. W. Pinkerton, and E. K. Wollenberg. 2009. Adaptive co-management for socialecological complexity. Frontiers in Ecology and the Environment 7:95-102. http://dx.doi.org/10.1890/070089

Baird, J., R. Plummer, and K. Pickering. In press. Priming the governance system for climate change adaptation: the application of a social-ecological inventory (SEI) to engage actors in Niagara, Canada. Ecology and Society.

Bergkamp, G., B. Orlando, and I. Burton. 2003. Change. Adaptation of water management to climate change. International Union for Conservation of Nature, Gland, Switzerland. http://dx.doi.org/10.2305/IUCN.CH.2003.WANI.1. $\underline{\text { en }}$

Berkes, F. 2009. Evolution of co-management: role of knowledge generation, bridging organizations and social learning. Journal of Environmental Management 90:1692-1702. http://dx.doi.org/10.1016/j.jenvman.2008.12.001

Berkes, F., and D. Armitage. 2010. Co-management institutions, knowledge, and learning: adapting to change in 
the Arctic. Inuit Studies 34(1):109-131. http://dx.doi. org/10.7202/045407ar

Berkes, F., D. Armitage, and N. Doubleday, editors. 2007. Synthesis: adapting, innovating, evolving. Pages 308-327 in D. Armitage, F. Berkes, and N. Doubleday, editors. Adaptive comanagement: collaboration, learning and multilevel governance. University of British Columbia Press, Vancouver, British Columbia, Canada.

Biermann, F., M. M. Betsill, J. Gupta, N. Kanie, L. Lebel, D. Liverman, H. Schroeder, and B. Siebenhüner. 2009. Earth system governance: people, places and the planet. Science and Implementation Plan of the Earth System Governance Project. ESG Report No. 1. The Earth System Governance Project, International Human Dimension Programme on Global Environmental Change, Bonn, Germany.

Bulkeley, H. 2005. Reconfiguring environmental governance: towards a politics of scales and networks. Political Geography 24(8):875-902. http://dx.doi.org/10.1016/j.polgeo.2005.07.002

Cundill, G. 2010. Monitoring social learning processes in adaptive comanagement: three case studies from South Africa. Ecology and Society 15(3): 28. [online] URL: http://www. ecologyandsociety.org/vol15/iss3/art28/

Cundill, G., and C. Fabricius. 2010. Monitoring the governance dimension of natural resource co-management. Ecology and Society 15(1): 15. [online] URL: http://www. ecologyandsociety.org/vol15/iss1/art15/

de Loë, R. C., D. Armitage, R. Plummer, S. Davidson, and L. Moraru. 2009. From government to governance: a state-ofthe-art review of environmental governance. Final Report. Prepared for Alberta Environment, Environmental Stewardship, Environmental Relations by Rob de Loë Consulting Services. Alberta Environment and Sustainable Resource Development, Edmonton, Alberta, Canada. [online] URL: http://www. environment.gov.ab.ca/info/posting.asp?assetid=8187\&categoryid $=5$

de Loë, R., and R. Plummer. 2010. Climate change, adaptive capacity, and governance for drinking water in Canada. Pages 157-178 in D. Armitage and R. Plummer, editors. Adaptive capacity and environmental governance. Springer-Verlag, Berlin, Germany. http://dx.doi.org/10.1007/978-3-642-12194-4 8

Dietz, T., E. Ostrom, and P. Stern. 2003. The struggle to govern the commons. Science 302:1907-12. http://dx.doi.org/10.1126/ $\underline{\text { science. } 1091015}$

Duit, A., and V. Galaz. 2008. Governance and complexityemerging issues for governance theory. Governance 21 (3):311-335. [online] URL: http://dx.doi.org/10.1111/ j.1468-0491.2008.00402.x
Engle, N. L. 2011. Adaptive capacity and its assessment. Global Environmental Change 21:647-656. http://dx.doi. org/10.1016/j.gloenvcha.2011.01.019

Fabricius, C., C. Folke, G. Cundill, and L. Schultz. 2007. Powerless spectators, coping actors, and adaptive comanagers: a synthesis of the role of communities in ecosystem management. Ecology and Society 12(1): 29. [online] URL: http://www.ecologyandsociety.org/vol12/iss1/art29/

Fennell, D., R. Plummer, and M. Marschke. 2008. Is adaptive co-management ethical? Journal of Environmental Management 88(1):62-75. http://dx.doi.org/10.1016/j.jenvman.2007.01.020

Folke, C. 2007. Social-ecological systems and adaptive governance of the commons. Ecological Research 22 (1):14-15. http://dx.doi.org/10.1007/s11284-006-0074-0

Folke, C., S. Carpenter, T. Elmqvist, L. Gunderson, C. S. Holling, B. Walker, J. Bengtsson, F. Berkes, J. Colding, K. Danell, M. Falkenmark, M. Moberg, L. Gordon, R. Kaspersson, N. Kautsky, A. Kinzig, S. A. Levin, K-G. Mäler, L. Ohlsson, P. Olsson, E. Ostrom, W. Reid, J. Rockstöm, S. Savenije, and U. Svedin. 2002. Resilience and sustainable development: building adaptive capacity in a world of transformations. Report for the Swedish Environmental Advisory Council 2002. Ministry of the Environment, Stockholm, Sweden.

Folke, C., S. R. Carpenter, B. Walker, M. Scheffer, T. Chapin, and J. Rockström. 2010. Resilience thinking: integrating resilience, adaptability and transformability. Ecology and Society 15(4): 20. [online] URL: http://www.ecologyandsociety. org/vol15/iss4/art20/

Folke, C., J. Colding, and F. Berkes. 2003. Synthesis: building resilience and adaptive capacity in social-ecological systems. Pages 352-387 in F. Berkes, J. Colding and C. Folke, editors. Navigating social-ecological systems: building resilience for complexity and change. Cambridge University Press, Cambridge, UK. http://dx.doi.org/10.1017/CBO9780511541957.020

Folke, C., T. Hahn, P. Olsson, and J. Norberg. 2005. Adaptive governance of social-ecological systems. Annual Review of Environment and Resources 30:441-473. http://dx.doi. org/10.1146/annurev.energy.30.050504.144511

Galaz, V., B. Crona, H. Österblom, P. Olsson, and C. Folke. 2012. Polycentric systems and interacting planetary boundaries - emerging governance of climate change - ocean acidification - marine biodiversity. Ecological Economics 81:21-32. http://dx.doi.org/10.1016/j.ecolecon.2011.11.012

Galaz, V., T. Hahn, P. Olsson, C. Folke, and U. Svedin. 2008. The problem of fit among biophysical systems, environmental and resource regimes, and broader governance systems: 
insights and emerging challenges. Pages 147-182 in O. Young, L. A. King, and H. Schroeder, editors. Institutions and environmental change: principal findings, applications, and research frontiers. MIT Press, Boston, Massachusetts, USA.

Glasbergen, P. 1998. The question of environmental governance. Pages 1-18 in P. Glasbergen, editor. Co-operative environmental governance: public-private agreements as a policy strategy. Kluwer Academic, Dordrecht, The Netherlands. http://dx.doi.org/10.1007/978-94-011-5143-6_1

Hahn, T. 2011. Self-organized governance networks for ecosystem management: who is accountable? Ecology and Society 16(2): 18. [online] URL: http://www.ecologyandsociety. org/vol16/iss2/art18/

Himley, M. 2008. Geographies of environmental governance: the nexus of nature and neoliberalism. Geography Compass 2(2):433-451. http://dx.doi.org/10.1111/j.1749-8198.2008.00094. $\underline{\mathrm{x}}$

Holling, C. S., and G. K. Meffe. 1996. Command and control and the pathology of natural resource management. Conservation Biology 10(2):328-337. http://dx.doi.org/10.1046/ j.1523-1739.1996.10020328.x

Huitema, D., E. Mostert, W. Egas, S. Moellenkamp, C. PahlWostl, and R. Yalcin. 2009. Adaptive water governance: assessing the institutional prescriptions of adaptive (co-) management from a governance perspective and defining a research agenda. Ecology and Society 14(1): 26. [online] URL: http://www.ecologyandsociety.org/vol14/iss1/art26/

Intergovernmental Panel on Climate Change (IPCC). 2007. Climate Change 2007: synthesis report. R. K. Pachauri, and A. Reisigner, editors. Contribution of Working Groups I, II and III to the Fourth Assessment Report of the Intergovernmental Panel on Climate Change. IPCC, Geneva, Switzerland. [online] URL: http://www.ipcc.ch/publications and data/ ar4/syr/en/contents.html

Kettl, D. F. 2002. Environmental governance: a report on the next generation of environmental policy. Brookings Institution Press, Harrisonburg, Virginia, USA.

Kofinas, G. P. 2009. Adaptive co-management in socialecological governance. Principles of Ecosystem Stewardship 1:77-101. http://dx.doi.org/10.1007/978-0-387-73033-2 4

Kooiman, J., editor. 1993. Modern governance: new government - society interactions. Sage, London, UK.

Lebel, L., J. M. Anderies, B. Campbell, C. Folke, S. HatfieldDodds, T. P. Hughes, and J. Wilson. 2006. Governance and the capacity to manage resilience in regional social-ecological systems. Ecology and Society 11(1): 19. [online] URL: http:// www.ecologyandsociety.org/vol11/iss 1/art19/
Lemos, M. C., and A. Agrawal. 2006. Environmental governance. Annual Review of Environment and Resources 31:297-325. http://dx.doi.org/10.1146/annurev. energy.31.042605.135621

Locatelli, B., M. Kanninen, M. Brockhaus, C. J. Pierce Colfer, D. Murdiyarso, and H. Santoso. 2008. Facing an uncertain future: how forests and people can adapt to climate change. Forest Perspectives 5. [online] URL: http://www.cifor.org/ publications/pdf_files/media/CIFOR adaptation.pdf

Lockwood, M., and J. Davidson. 2010. Environmental governance and the hybrid regime of Australian natural resource management. Geoforum 41:388-398. http://dx.doi. org/10.1016/j.geoforum.2009.12.001

Lockwood, M., J. Davidson, A. Curtis, E. Stratford, and R. Griffith. 2010. Governance principles for natural resource management. Society and Natural Resources 23(10):986-1001. http://dx.doi.org/10.1080/08941920802178214

Milly, P. C. D., J. Betancourt, M. Falkenmark, R. M. Hirsch, Z. W. Kindzewicz, D. P. Lettenmaier, and R. J. Stouffer. 2008. Stationarity is dead: whither water management? Science 319 (5863):573-574. http://dx.doi.org/10.1126/science.1151915

Nadasdy, P. 2007. Adaptive co-management and the gospel of resilience. Pages 208-227 in D. Armitage, F. Berkes, and N. Doubleday, editors. Adaptive co-management: collaboration, learning and multilevel governance. University of British Columbia Press, Vancouver, British Columbia, Canada.

National Research Council of the National Academies (NRC). 2009. Informing decisions in a changing climate. Panel on Strategies and Methods for Climate-Related Decision Support. National Academies, Washington, D.C., USA.

Nelson, D. R., W. N. Adger, and K. Brown. 2007. Adaptation to environmental change: contributions of a resilience framework. Annual Review in Environment and Natural Resources 32:395-419. http://dx.doi.org/10.1146/annurev. energy.32.051807.090348

Olsson, P., Ö. Bodin, and C. Folke. 2010. Building transformative capacity for ecosystem stewardship in socialecological systems: insights and challenges. Pages 263-286 in D. Armitage, and R. Plummer, editors. Adaptive capacity and environmental governance. Springer Verlag, New York, New York, USA. http://dx.doi.org/10.1007/978-3-642-12194-4 13

Olsson, P., C. Folke, and F. Berkes. 2004a. Adaptive comanagement for building resilience in social-ecological systems. Environmental Management 34(1):75-90. http://dx. doi.org/10.1007/s00267-003-0101-7

Olsson, P., C. Folke, V. Galaz, T. Hahn, and L. Schultz. 2007. Enhancing the fit through adaptive co-management: creating 
and maintaining bridging functions for matching scales in the Kristianstads Vattenrike Biosphere Reserve Sweden. Ecology and Society 12(1): 28. [online] URL: http://www. ecologyandsociety.org/vol12/iss1/art28/

Olsson, P., C. Folke, and T. Hahn. 2004b. Social-ecological transformation for ecosystem management: the development of adaptive co-management of a wetland landscape in southern Sweden. Ecology and Society 9(4): 2. [online] URL: http:// www.ecologyandsociety.org/vol9/iss4/art2

Olsson, P., C. Folke, and T. Hughes. 2008. Navigating the transition to ecosystem-based management of the Great Barrier Reef, Australia. Proceedings of the National Academy of Sciences 105:9489-9494. http://dx.doi.org/10.1073/ pnas.0706905105

Olsson, P., L. H. Gunderson, S. R. Carpenter, P. Ryan, L. Lebel, C. Folke, and C. S. Holling. 2006. Shooting the rapids: navigating transitions to adaptive governance of socialecological systems. Ecology and Society 11(1): 18. [online] URL: http://www.ecologyandsociety.org/vol11/iss1/art18/

Ostrom, E. 2007. A diagnostic approach for going beyond panaceas. Proceedings of the National Academy of Science 104:15181-15187. http://dx.doi.org/10.1073/pnas.0702288104

Paavola, J. 2007. Institutions and environmental governance: a reconceptualization. Ecological Economics 63(1):93-103. http://dx.doi.org/10.1016/j.ecolecon.2006.09.026

Pahl-Wostl, C., J. Gupta, and D. Petry. 2008. Governance and the global water system: a theoretical exploration. Global Governance 14:419-435. [online] URL: http://journals. rienner.com/doi/abs/10.5555/ggov.2008.14.4.419

Pelling, M., C. High, J. Dearing, and D. Smith. 2008. Shadow spaces for social learning: a relational understanding of adaptive capacity to climate change within organisations. Environment and Planning A 40:867-884. http://dx.doi. org/10.1068/a39148

Plummer, R. 2009. The adaptive co-management process: an initial synthesis of representative models and influential variables. Ecology and Society 14(2): 24. [online] URL: http:// www.ecologyandsociety.org/vol14/iss2/art24/

Plummer, R., and D. R. Armitage. 2007. Charting the new territory of adaptive co-management: a Delphi study. Ecology and Society 12(2): 10. [online] URL: http://www. ecologyandsociety.org/vol12/iss2/art10/

Plummer, R., and D. Armitage. 2010. Integrating perspectives on adaptive capacity and environmental governance. Pages 1-9 in D. Armitage and R. Plummer, editors. Adaptive capacity and environmental governance. Springer-Verlag, New York, New York, USA. http://dx.doi.org/10.1007/978-3-642-12194-4 1
Plummer, R., D. R. Armitage, and R. C. de Löe. 2013. Adaptive co-management and its relationship to environmental governance. Ecology and Society. 18(1): 21. http://dx.doi. org/10.5751/ES-05383-180121

Plummer, R., B. Crona, D. R. Armitage, P. Olsson, M. Tengö, and O. Yudina. 2012. Adaptive comanagement: a systematic review and analysis. Ecology and Society 17(3): 11. http://dx. doi.org/10.5751/ES-04952-170311

Plummer, R., and J. E. FitzGibbon. 2007. Connecting adaptive co-management, social learning and social capital through theory and practice. Pages 38-61 in D. Armitage, F. Berkes, and N. Doubleday, editors. Adaptive co-management: collaboration, learning and multilevel governance. University of British Columbia Press, Vancouver, British Columbia, Canada.

Plummer, R., and A. Hashimoto. 2011. Adaptive comanagement and the need for situated thinking in collaborative conservation. Human Dimensions of Wildlife 16(4):222-235. http://dx.doi.org/10.1080/10871209.2011.585434

Reed, M. G., and S. Bruyneel. 2010. Rescaling environmental governance, rethinking the state: a three-dimensional review. Progress in Human Geography 34(5):646-653. http://dx.doi. org/10.1177/0309132509354836

Rockström, J., W. Steffen, K. Noone, Å. Persson, F. S. Chapin III, E. F. Lambin, T. M. Lenton, M. Scheffer, C. Folke, H. J. Schellnhuber, B. Nykvist, C. A. de Wit, T. Hughes, S. van der Leeuw, H. Rodhe, S. Sörlin, P. K. Snyder, R. Costanza, U. Svedin, M. Falkenmark, L. Karlberg, R. W. Corell, V. J. Fabry, J. Hansen, B. Walker, D. Liverman, K. Richardson, P. Crutzen, and J. A. Foley. 2009. A safe operating space for humanity. Nature 461:472-475. http://dx.doi.org/10.1038/461472a

Scheffer, M. 2009. Critical transitions in nature and society. Princeton University Press, Princeton, New Jersey, USA.

Scheffer, M., J. Bascompte, W. A. Brock, V. Brovkin, S. R. Carpenter, V. Dakos, H. Held, E. H. van Ness, M. Rietkerk, and G. Sugihara. 2009. Early-warning signals for critical transitions. Nature 461(3):53-59. http://dx.doi.org/10.1038/ $\underline{\text { nature } 08227}$

Schultz, L. 2009. Nurturing resilience in social-ecological systems: lessons learned from bridging organizations. Stockholm University, Stockholm, Sweden.

Smit, B., and O. Pilifosova. 2001. Adaptation to climate change in the context of sustainable development and equity. Pages 879-906 in J. J. McCarthy, O. F. Canziani, N. A. Leary, D. J. Dokken, and K. S. White, editors. Climate Change 2001: impacts, adaptation and vulnerability. Contribution of Working Group II to the Third Assessment Report of the Intergovernmental Panel on Climate Change. Cambridge University Press, Cambridge, UK. 
Smit, B., and O. Pilifosova. 2003. From adaptation to adaptive capacity and vulnerability reduction. Pages 9-28 in J. B. Smith, R. J. T. Klein, and S. Huq, editors. Climate change, adaptive capacity and development. Imperial Collect Press, London, UK. http://dx.doi.org/10.1142/97818609458160002

Smit, B., and J. Wandel. 2006. Adaptation, adaptive capacity and vulnerability. Global Environmental Change 16:282-292. http://dx.doi.org/10.1016/j.gloenvcha.2006.03.008

Smithers, J., and B. Smit. 1997. Human adaptation to climatic variability and change. Global Environmental Change 7 (2):129-146. http://dx.doi.org/10.1016/S0959-3780(97)00003-4

Tompkins, E. L., and H. Eakin. 2012. Managing private and public adaptation to climate change. Global Environmental Change 22:3-11. http://dx.doi.org/10.1016/j.gloenvcha.2011.09.010

van Nieuwaal, K., P. Driessen, T. Spit, and K. Termeer. 2009. A state of the art governance literature on adaptation to climate change: towards a research agenda. IOP Conference Series: Earth and Environmental Science 6 http://dx.doi. org/10.1088/1755-1307/6/36/362019

Walker, B. H., C. S. Holling, S. R. Carpenter, and A. Kinzig. 2004. Resilience, adaptability and transformability in socialecological systems. Ecology and Society 9(2): 5. [online] URL: http://www.ecologyandsociety.org/vol9/iss2/art5/ 